\title{
Estabelecimento in vitro de oliveira cv. “Arbequina” para início da micropropagação
}

\author{
In vitro establishment of olive tree cultivar 'Arbequina' for micropropagation starting
}

\author{
Lorena Pastorini Donini ${ }^{\mathrm{I}}$ Márcia Wulff Schuch ${ }^{\mathrm{II}}$ Mirian de Farias Ribeiro ${ }^{\mathrm{II}}$ \\ Joseane Almeida de SouzaII Gustavo Campos Soares ${ }^{\text {II }}$
}

\begin{abstract}
-NOTA-
RESUMO

A utilização de técnicas de cultura de tecidos com o objetivo de melhorar a rentabilidade das culturas tem-se apresentado como um instrumento importante que pode ser explorado pelos pesquisadores, produzindo plantas com elevada qualidade sanitária. Este trabalho teve como objetivo determinar o meio de cultura e a concentração de zeatina adequadas no estabelecimento in vitro de oliveira "Arbequina". Foram utilizados segmentos nodais $(1 \mathrm{~cm})$, obtidos de plantas mantidas em casa de vegetação. Em laboratório, o material foi desinfestado com álcool 70\% (um minuto) e solução de hipoclorito de sódio $(2,5 \%)$, por 15 minutos, e inoculado em meio MO, MS ou WPM, adicionados de diferentes concentrações de zeatina $\left(0,2\right.$ e $\left.4 \mathrm{mg} \mathrm{L}^{-1}\right)$. $O$ material foi mantido em sala de crescimento a $25 \pm 2^{\circ} \mathrm{C}$, no escuro, por uma semana. Depois, foi transferido para luz, fotoperíodo de 16 horas e densidade de fluxo de fótons de $27 \mu \mathrm{mol} \mathrm{m} \mathrm{m}^{-2} \mathrm{~s}^{-1}$. Aos sete, 14 e 21 dias o material foi avaliado

produce plants with high sanitary quality. This research aimed to determine both the suitable culture medium and zeatin concentration for in vitro establishment of olive tree cultivar 'Arbequina'. The $1 \mathrm{~cm}$ nodal segments were obtained from plants grown in the greenhouse. In the laboratory, the material was disinfested with 70\% alcohol (1 minute) and in a 2.5\% hypochlorite solution for 15 minutes. Then they were inoculated onto MO, MS or WPM medium enriched of different zeatin concentrations $\left(0,2\right.$ and $\left.4 \mathrm{mg} \mathrm{L}^{-1}\right)$. The material was kept in growth room at $25 \pm 2^{\circ} \mathrm{C}$ under dark conditions for a week. After darkness, they were transferred to light, 16-hour photoperiod and photon flux density of $27 \mu \mathrm{mol} \mathrm{m} \mathrm{m}^{-2} \mathrm{~s}^{-1}$. On the $7^{\text {th }}, 14^{\text {th }}$ and $21^{\text {st }}$ day, the fungal and bacterial contamination and explants oxidation percentage were evaluated. On the $45^{\text {th }}$ day of cultivation the material was assessed regarding to the survival rate, establishment of explants, shoots number and length, and leaves number. The present research concluded that the WPM medium showed the better performances, followed by $M O$ medium.
\end{abstract} quanto à percentagem de contaminação bacteriana, percentagem de contaminação fúngica e percentagem de explantes oxidados. Aos 45 dias de cultivo, o material foi avaliado quanto à percentagem de sobrevivência, à percentagem de estabelecimento, ao número de brotações, ao comprimento de brotações e ao número de folhas. Os resultados permitiram concluir que o material mantido em meio WPM apresentou melhores resultados, seguidos do meio MO.

Palavras-chave: Oleaceae, Olea europaea, produção de mudas, micropropagação.

\section{ABSTRACT}

The use of tissues culture techniques aiming to improve the profitability of the cultures has been presented as an important tool that may be explored by researchers to
Key words: Oleaceae, Olea europaea, seedlings production, micropropagation.

A oliveira (Olea europaea L.) pertence à família Oleaceae que inclui até 30 gêneros e 600 espécies distribuídas por regiões tropicais e temperadas (CORRÊA et al., 2002; OLIVEIRA \& ABRAHÃO, 2006). Ela é originária da região geográfica que vai desde o sul do Cáucaso até as planícies do Irã, Palestina e zona costeira da Síria e estende-se até povoar todos os países às margens do Mediterrâneo (MESQUITA et al., 2006).

\footnotetext{
'Laboratório de Micropropagação de Plantas Frutíferas, Departamento de Fitotecnia, Faculdade de Agronomia Eliseu Maciel, Universidade Federal de Pelotas (UFPel), Pelotas, RS, Brasil. E-mail: lorenadonini@yahoo.com.br. Autor para correspondência.

IUniversidade Federal de Pelotas (UFPel), Pelotas, RS, Brasil.
} 
Na Espanha, a cultivar “Arbequina” é uma das mais importantes devido as suas características de vigor vegetativo, precocidade, alto rendimento em azeite e boa resistência ao ataque de pragas e doenças (OLIVEIRA et al., 2003). Apesar de ser uma cultura introduzida no Brasil há muitas décadas, o cultivo da oliveira não prosperou, devido à falta de estudos científicos e da adaptação tecnológica, não havendo plantio em escala comercial (MESQUITA et al., 2006; OLIVEIRA et al., 2006a). Dos países da América do Sul, o Brasil é um dos maiores importadores de produtos de oliveira, sendo a Argentina um dos maiores fornecedores, além da Espanha e de Portugal (PIO et al., 2005). Nos últimos anos, a olivicultura passou a despertar interesse entre produtores rurais, principalmente no sul de Minas Gerais (OLIVEIRA et al., 2006).

A utilização de técnicas de cultura de tecidos com o objetivo de melhorar a rentabilidade das culturas tem-se apresentado como um instrumento importante que pode ser explorado pelos pesquisadores (OLIVEIRA et al., 2006a), produzindo plantas com elevada qualidade sanitária (SOUZA et al., 2006). Durante o estabelecimento in vitro, a adição de fitorreguladores tem o objetivo principal de suprir as possíveis deficiências dos teores endógenos de hormônios nos explantes que se encontram isolados das regiões produtoras na planta-matriz. Simultaneamente, a adição de fitorreguladores estimula certas respostas como o alongamento ou a multiplicação da parte aérea. A adição de citocinina é favorável e pode variar bastante em função da espécie e do tipo de explante (GRATTAPAGLIA\& MACHADO, 1998).

A utilização do meio MO adicionado de zeatina promoveu uma maior número de folhas que os outros meios utilizados no cultivo de oliveira "Maderensis" (SANTOS et al., 2003). No cultivo de oliveira "hondrolia Chalkidikis", GRIGORIADOU et al. (2002) observaram que, entre os meios de cultura testados para esta cultivar, o meio WPM promoveu os melhores resultados e a combinação de $20 \mu \mathrm{M}$ de zeatina com $10 \mu \mathrm{M}$ de $\mathrm{GA}_{3}$ afetou positivamente o número de brotação por explante.

Visando a produção de mudas de oliveira via cultura de tecidos, este trabalho teve como objetivo determinar o meio de cultura e a concentração de zeatina adequada no estabelecimento in vitro de oliveira "Arbequina".

O presente trabalho foi realizado no Laboratório de Micropropagação de Plantas Frutíferas, Departamento de Fitotecnia da Faculdade de Agronomia Eliseu Maciel, da Universidade Federal de
Pelotas, RS. Para o estabelecimento in vitro, foram utilizados segmentos nodais com aproximadamente $1 \mathrm{~cm}$ de comprimento, obtidos de brotações novas de plantas de oliveira "Arbequina", mantidas em casa de vegetação. Visando diminuir a contaminação in vitro, as mudas foram pulverizadas com o antibiótico Agrimicina (Estreptomicina) e o fungicida Cercobin, nas doses de 2,4 e 0,7g L $\mathrm{g}^{-1}$, respectivamente. Em laboratório, foram retiradas as folhas na altura do pecíolo e o material foi desinfestado com imersão em álcool $70 \%$ por 1 minuto, seguido de imersão em solução de hipoclorito de sódio ( $2,5 \%$ do principio ativo), adicionado de uma gota de Tween 20, durante 15 minutos. Após este período, o material foi lavado por três vezes em água destilada esterilizada e foram retirados os explantes (segmentos nodais).

Os meios de cultura utilizados foram constituídos pelos sais e pelas vitaminas do MO (RUGGINI, 1984), pelos sais e pelas vitaminas do MS (MURASHIGE \& SKOOG, 1962) e pelos sais e pelas vitaminas do WPM (LLOYD \& MCCOWN, 1980), adicionados de diferentes concentrações de zeatina (zero, dois e quatro $\left.\mathrm{mg} \mathrm{L}^{-1}\right)$. $\mathrm{O} \mathrm{pH}(5,8)$ foi ajustado antes da inclusão do ágar $(0,8 \%)$ e o meio foi autoclavado a $121^{\circ} \mathrm{C}$ e 1,5 atm por 20 minutos. Foram utilizados tubos de ensaio (20x150mm) com oito $\mathrm{mL}$ de meio de cultura. Após a inoculação, os explantes foram mantidos em sala de crescimento a $25 \pm 2^{\circ} \mathrm{C}$, no escuro, por um período de sete dias, visando a diminuição de oxidação. Depois desse período, o material foi transferido para luz, fotoperíodo de 16 horas e densidade de fluxo de fótons de $27 \mu \mathrm{mol} \mathrm{m}^{-2} \mathrm{~s}^{-1}$.

Os tratamentos constituiram-se de três meios de cultura (MO, MS e WPM) e três concentrações de zeatina (zero, dois e quatro $\mathrm{mg} \mathrm{L}^{-1}$ ), num fatorial $3 \times 3$, totalizando nove tratamentos. O delineamento experimental utilizado foi inteiramente casualizado com quatro repetições por tratamento, sendo que cada repetição constituiu-se de cinco tubos, com um explante cada. Foram realizadas avaliações aos sete, 14 e 21 dias quanto à percentagem de contaminação bacteriana, percentagem de contaminação fúngica e percentagem de explantes oxidados. Aos 45 dias de cultivo, o material foi avaliado quanto à percentagem de sobrevivência, indicada pela coloração verde do segmento nodal, quanto à percentagem de estabelecimento, que foi determinado pelo desenvolvimento de primórdios foliares (presença de folhas ou brotações), número de brotações, comprimento de brotações e número de folhas/ brotação. Os dados foram submetidos à análise de variância e as médias dos tratamentos comparadas estatisticamente pelo teste de Duncan $(\alpha=0,05)$, por 
meio do uso do programa estatístico SANEST (ZONTA \& MACHADO, 1984). Os dados foram transformados em arco seno da raiz quadrada de $\mathrm{x} / 100$, em que $\mathrm{x}$ é o percentual obtido.

Na tabela 1 pode-se observar que os explantes cultivados em meio MS apresentaram maior percentagem de contaminação fúngica (92,95\%). De acordo com ERIG \& SCHUCH(2003), as plantas lenhosas, em que é incluída a maioria das plantas frutíferas, apresentam dificuldades para o estabelecimento in vitro, principalmente devido à contaminação e oxidação. A maior contaminação fúngica também pode ter ocorrido por ainda não ter se estabelecido um protocolo de desinfestação de oliveira para esta cultivar. Para sobrevivência, estabelecimento e número de brotações, os explantes cultivados em meio WPM apresentaram as maiores médias, não diferindo de quando cultivados no meio MO (Tabela 1). A baixa taxa de sobrevivência e de estabelecimento também se deve pela alta percentagem de contaminação e não em relação aos meios de cultura utilizados. Também foi observado que todos os explantes sobreviventes estavam estabelecidos, sendo que isso nem sempre pode ser um indicativo, pois a sobrevivência nem sempre indicará estabelecimento (ERIG \& SCHUCH, 2003).

Os explantes estabelecidos em meio $\mathrm{MO}+$ $4 \mathrm{mg} \mathrm{L}^{-1}$ apresentaram uma melhor aparência em relação aos demais, embora não tenha sido estatisticamente o melhor meio de cultura para sobrevivência e estabelecimento. Este meio de cultura (MO) também apresentou maiores médias de comprimento de brotações $(0,17 \mathrm{~cm})$ e número de folhas por brotação (1,31 folhas/brotação).

No estabelecimento in vitro de aceroleira, MELO et al. (1999) não observaram diferenças para número de brotações entre os meios utilizados (MS, WPM, DKW), ao contrário de presente trabalho, quando foram observadas diferenças entre os meios de cultivo para o número de brotações de oliveira, sendo que o meio WPM proporcionou maiores médias seguido do meio MO. No estabelecimento in vitro de mirtilo cv. "Florida", ERIG \& SCHUCH(2005) obtiveram médias de $88,64 \%$ de sobrevivência, independente da constituição dos fitorreguladores utilizados, e $70,74 \%$ de estabelecimento quando utilizaram o meio de cultura WPM acrescido de 24,6 $\mu \mathrm{M}$ de 2iP. No presente trabalho, as maiores médias de sobrevivência e estabelecimento foram obtidas quando se utilizou o meio WPM, independente da utilização do fitorregulador, pois só houve diferença para o fator meio de cultura.

Em experimento de estabelecimento de oliveira, "Koroneiki”, ROUSSOS \& PONTIKIS (2002) utilizaram diferentes meios de cultura, incluindo MO, WPM, DKW, e observaram que os explantes apresentaram melhores respostas quando cultivados por um mês em meio DKW modificado. Em experimento seguinte, esses autores também observaram que adição de $1-2 \mathrm{mg} \mathrm{L}^{-1}$ de zeatina ou $0,1-0,2 \mathrm{mg} \mathrm{L}^{-1}$ de TDZ promoveram maior número de brotos, média de 1,5 brotos. De acordo com ROUSSOS \& PONTIKIS (2002), a zeatina é preferida pela oliveira, mas é uma citocinina extremamente cara e poderia ser substituída no meio de cultura por uma combinação de TDZ com giberelina.

Os meios de cultura WPM e MO proporcionam melhores resultados no estabelecimento de oliveira "Arbequina”. Em virtude do alto índice de contaminação, é necessária realização de experimento que determine a melhor concentração de hipoclorito para desinfestação.

Tabela 1 - Média de contaminação bacteriana, contaminação fúngica, oxidação, sobrevivência, estabelecimento, número médio de brotações, comprimento de brotações e número de folhas/brotação de explantes de oliveira (Olea europaea L.) "Arbequina" em diferentes meios de cultura e concentrações de zeatina. UFPel, Pelotas-RS, 2006.

\begin{tabular}{|c|c|c|c|c|c|c|}
\hline \multirow{2}{*}{ Avaliação } & \multirow{2}{*}{ Variáveis } & \multicolumn{3}{|c|}{-------------Meios------------ } & \multirow{2}{*}{ Média geral } & \multirow{2}{*}{$\begin{array}{c}\text { Coeficiente de variação } \\
(\%)\end{array}$} \\
\hline & & MS & $\mathrm{MO}$ & WPM & & \\
\hline \multirow{4}{*}{$\frac{\mathscr{n}}{\stackrel{\tilde{\theta}}{\Xi}}$} & Contaminação bacteriana $(\%)$ & $2,37 \mathrm{a}$ & $1,33 \mathrm{a}$ & $0,32 \mathrm{a}$ & 1,47 & 424,26 \\
\hline & Contaminação fúngica (\%) & $92,95 \mathrm{a}$ & $75,71 \mathrm{~b}$ & $67,56 \mathrm{~b}$ & 51,95 & 37,05 \\
\hline & Oxidação (\%) & $1,33 \mathrm{a}$ & $0,59 \mathrm{a}$ & $0,00 \mathrm{a}$ & 1,47 & 424,26 \\
\hline & Sobrevivência (\%) & $3,68 \mathrm{~b}$ & $15,25 \mathrm{ab}$ & $24,14 \mathrm{a}$ & 21,16 & 71,43 \\
\hline \multirow{4}{*}{$\begin{array}{l}\stackrel{\tilde{E}}{\tilde{\theta}} \\
\stackrel{\sim}{f}\end{array}$} & Estabelecimento (\%) & $3,68 \mathrm{~b}$ & $15,25 \mathrm{ab}$ & $24,14 \mathrm{a}$ & 21,16 & 71,43 \\
\hline & Número de brotações & $0,15 \mathrm{~b}$ & $0,36 \mathrm{ab}$ & $0,48 \mathrm{a}$ & 0,91 & 18,04 \\
\hline & Comprimento brotações $(\mathrm{cm})$ & $0,09 \mathrm{a}$ & $0,17 \mathrm{a}$ & $0,10 \mathrm{a}$ & 0,12 & 120,14 \\
\hline & Número de folhas/brotação & $0,47 \mathrm{a}$ & $1,31 \mathrm{a}$ & $1,12 \mathrm{a}$ & 1,20 & 39,69 \\
\hline
\end{tabular}

Médias não seguidas de mesma letra minúsculas nas linhas diferem entre si pelo teste de Duncan ao nível de $5 \%$ de probabilidade de erro. 


\section{REFERÊNCIAS}

CORRÊA, M.J.P. et al. Caracterización histoquímica de la etapa temprana del desarrollo del fruto del olivo (Olea europaea L.). Acta Botânica Brasilica, v.16, n.1, p.77-82, 2002.

ERIG, A.C.; SCHUCH, M.W. Tipo de explante e controle da contaminação e oxidação no estabelecimento in vitro de plantas de macieira (Malus domestica BORKH.) cvs. Galaxy, Maxigala e Mastergala. Revista Brasileira de Agrociência, v.9, n.3, p.221-227, 2003.

ERIG, A.C.; SCHUCH, M.W. Estabelecimento in vitro de mirtilo a partir de segmentos nodais. Scientia Agrária, v.6, n.2, p.91-96, 2005.

GRATTAPAGLIA, D.; MACHADO, M.A. Micropropagação. In: TORRES, A.C. Cultura de tecidos e transformação genética de plantas. Brasília: Embrapa SPI / Embrapa CNPH, 1998. 864p.

GRIGORIADOU, K. et al. In vitro propagation of the Greek olive cultivar 'Chondrolia Chalkidikis'. Plant Cell, Tissue and Organ Culture, v.71, p.47-54, 2002.

LLOYD, G.; MCCOWN, B. Commercially-feasible micropropagation of mountain laurel, kalmia latifolia, by use os shoot-tip culture. Combined Proceedings International Plant Propagators Society, v.30, p.421-427, 1980.

MELO, N.F. et al. Estabelecimento do cultivo in vitro de aceroleira (Malpighia emarginata DC.). Ciência e Agrotecnologia, v.23, n.1, p.102-107, 1999.

MESQUITA, D.L. et al. Aspectos econômicos da produção e comercialização do azeite de oliva e da azeitona. Informe Agropecuário, v.27, n.231, p.7-12, 2006.

MURASHIGE, T.; SKOOG, F. A revised medium for rapid growth and biossay with tabacco tissue cultures. Physiologia Plantarum, v.15, p.473-497, 1962.
OLIVEIRA, A.F. et al. Influência do número de nós em estacas semilenhosas de oliveira (Olea europaea L.) no enraizamento sob câmara de nebulização. Ciência Agrotecnológica, v.27, n.2, p.332-338, 2003.

OLIVEIRA, A.F.; ABRAHÃO, E. Botânica e morfologia da oliveira (Olea europaea L.). Informe agropecuário, v.27, n.231, p.13-17, 2006.

OLIVEIRA, A.F. et al. Caracterização morfológica de culivares de oliveira em coleção e considerações sobre o seu cultivo no Brasil. Informe agropecuário, v.27, n.231, p.55-62, 2006a.

PIO, R. et al. Enraizamento de diferentes tipos de estacas de oliveira (Olea europaea L.) utilizando ácido indolbutírico. Ciência Agrotecnológica, v.29, n.3, p.562-567, 2005.

ROUSSOS, P.A.; PONTIKIS, C.A. In vitro propagation of olive (Olea europaea L.) cv. Koroneiki. Plant Growth Regulation, v.37, p.295-304, 2002.

RUGINI, E. In vitro propagation of some olive (Olea europaea sativa L.) cultivars with different root-ability, and medium development using analytical data from developing shoots and embryos. Scientia Horticulturae, v.24, n.2, p.123-134, 1984.

SANTOS, C.V. et al. In vitro regeneration of Olea europaea ssp. Maderensis. Scientia Horticulturae, v.97, p.83-87. 2003.

SOUZA, J.A. et al. Efeito do tipo de ramo e do regime de luz fornecido à planta matriz no estabelecimento in vitro de araçazeiro cv. "Irapuã". Ciência Rural, v.36, n.6, p.19201922, 2006.

ZONTA, E.P., MACHADO, A.A. SANEST - Sistema de análise estatística para microcomputadores. Pelotas: DMEC/IFM/UFPel, 1984. 138p. 